\title{
Physiological and Molecular Mechanisms Underlying Graft Compatibility
}

\author{
Ana Pina, ${ }^{1 *}$ Sarah Jane Cookson, ${ }^{2}$ Angeles Calatayud,${ }^{3}$ \\ Alessandra Trinchera ${ }^{4}$ and PIlar ERrea ${ }^{1}$ \\ 'Instituto Agroalimentario de Aragón (CITA Universidad de Zaragossa), \\ Zaragoza, Spain; 'Institut des Sciences de la Vigne et du Vin, INRA/ \\ Université de Bordeaux, Bordeaux, France; ' Instituto Valenciano de \\ Investigaciones Agrarias, Valencia, Spain; ${ }^{4}$ Centro di ricerca Agricoltura e \\ Ambiente, CREA, Rome, Italy
}

\subsection{Introduction}

Grafting has been used for millennia to increase uniformity, vigour and resistance to biotic and abiotic stresses (e.g. low soil temperature, drought, salinity and flooding) of vegetatively propagated plants (Hartmann et al., 2002; Lee and Oda, 2003; Mudge et al., 2009). The grafting technique plays an important role in the production of horticultural crops, including fruit trees, ornamental plants and vegetable crops (Lee and Oda, 2003); it can be considered an important and alternative innovative practice of integrated pest management and a promising alternative for soil fumigants in vegetable production (Guan et al., 2012). Currently, although the use of grafted plants is increasing rapidly, the practice of grafting remains limited, mainly due to inconsistent grafting success (Hartmann et al., 2002). Considering the variation of graft compatibility between even closely related species, it is necessary to evaluate graft compatibility before considering the use of a rootstock with a specific scion genotype (Lee et al., 2010; Guan et al., 2012). Although a number of rootstocks are available, little information is provided related to scion-rootstock compatibility. This issue should be considered, as the performance of a grafted plant depends on the properties of the scion and rootstock genotypes, the compatibility of the rootstock with the scion, environmental conditions and cultivation methods (Andrews and Serrano-Marquez, 1993; Lee, 1994). Given the relative importance of graft compatibility throughout the world,

* apina@aragon.es 
there has been surprisingly little research dedicated to the study of this phenomenon. The large number of genotypes that can be combined by grafting produces a wide range of different physiological, biochemical and anatomical interactions to study, slowing down the progress in this research area.

The aim of this chapter is to review the biology of grafting and the factors influencing graft compatibility, focusing on the molecular and physiological aspects affecting graft development and success in herbaceous and woody plants.

\subsection{Anatomical and Physiological Steps During Graft Union Development}

\subsubsection{Graft establishment between compatible and incompatible combinations}

The general cellular events that occur after grafting are quite well known and are common to woody and herbaceous plants. These events include adhesion of the two graft partners, callus cell proliferation at the graft interface and cross-bridge formation of the vascular bundle to establish a functional vascular connection. All of these steps can determine the future of a grafted plant.

When the cut tissues of a scion and a rootstock come into intimate contact, the formation of parenchymatous cells capable of interlocking them starts, favouring the development of scion-rootstock connections. Studies on artichoke-cardoon grafts showed that, when scion-rootstock compatibility is good, filamentous connections between the rootstock and scion are formed 3 days after grafting (DAG), with the appearance of horizontal bridges over time (Trinchera et al., 2013). The formation of these horizontal bridges corresponds to the beginning of scionrootstock connectivity and represents the first skeleton of the undifferentiated cell callus development in response to wounding (Fig. 5.1).

These early cell interconnections, with a tubular feature similar to cell-wall projections, suggest an active role of cell recognition in promoting cambium tissue contact (Miller and Barnett, 1993). In artichoke-cardoon grafts, large-diameter structures $(3-8 \mu \mathrm{M})$ described as 'macrotubules' were observed at 3 DAG, indicating that these structures are formed during early contact between both graft partners (Fig. 5.2). These structures probably facilitate water and nutrient flow, and promote the exchange of signalling molecules across the grafting interface (Trinchera et al., 2013).

Another aspect related to the parenchymatous callus formation at the graft junction is the adhesion of the two partners, mediated in higher plants by the activation of the dictyosomes of Golgi bodies, which secrete a mixture of pectins, carbohydrates and proteins at the grafting interface (Moore and Walker, 1981). The accumulation of pectic carbohydrate material on the graft interface tissues during the first days after grafting has been shown in herbaceous (Fig. 5.2; Trinchera et al., 2013) and woody (Miller and Barnett, 1993; Pina et al., 2012) plants.

From the newly formed callus, new cambial cells differentiate, forming a continuous cambial connection between the scion and rootstock. Furthermore, prior to the binding of vascular cambium across the callus bridge, the initial xylem 


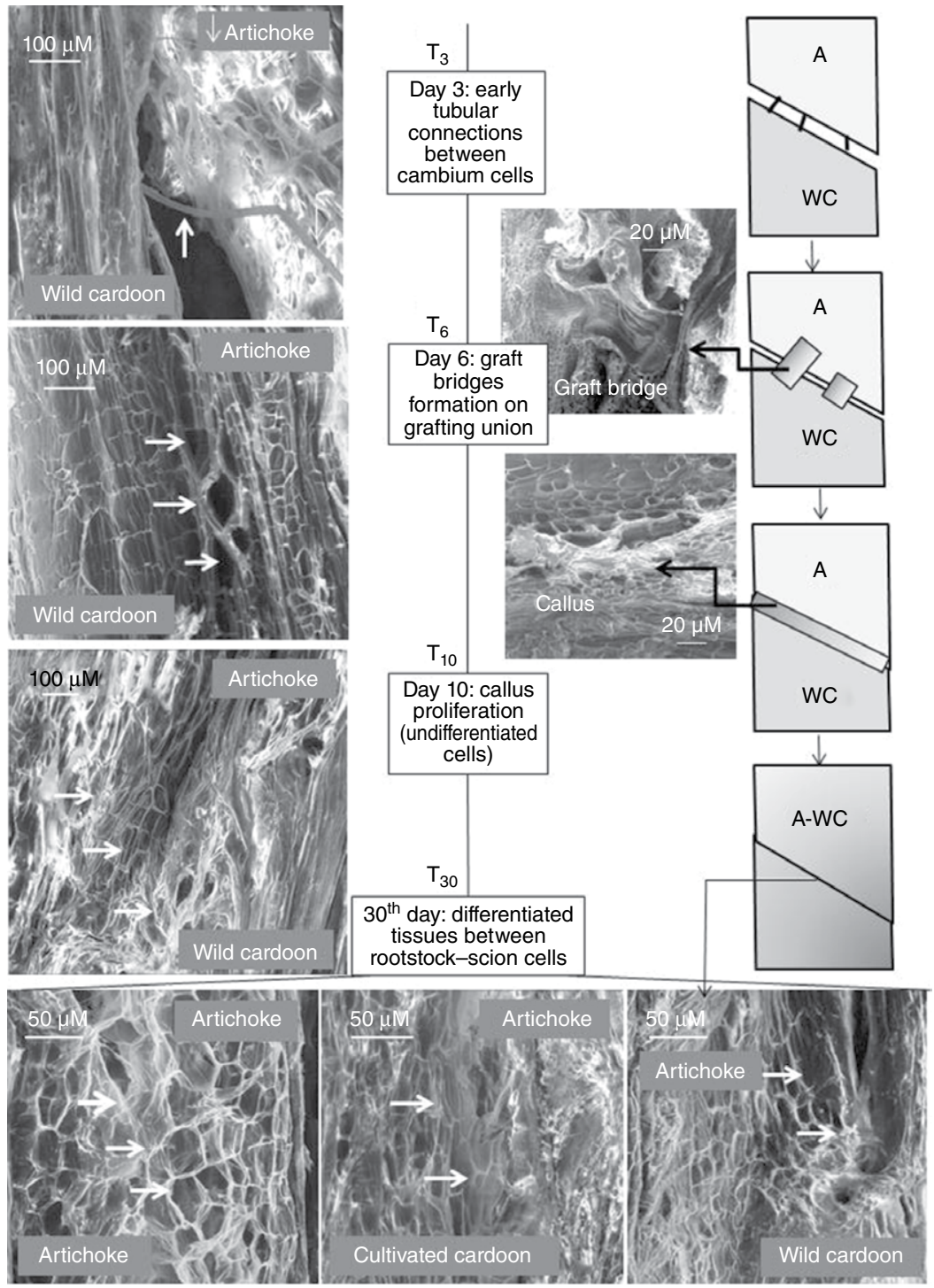

Fig. 5.1. Schematic representation of graft union formation between globe artichoke (A) and wild cardoon (WC), and related images by scanning electron microscopy showing the variable pressure of graft union formation in artichoke-artichoke, artichoke-cultivated cardoon and artichoke-wild cardoon combinations. (From Trinchera et al., 2013, with permission.)

and phloem can be differentiated, permitting the vascular connection between the scion and the rootstock (Hartmann et al., 2002). In melon-pumpkin grafts, Aloni et al. (2008) suggested two stages for graft union formation: an initial stage, in which vascular connections from the two partners are reunited (14 DAG) and a second phase in which graft incompatibility or compatibility is expressed 


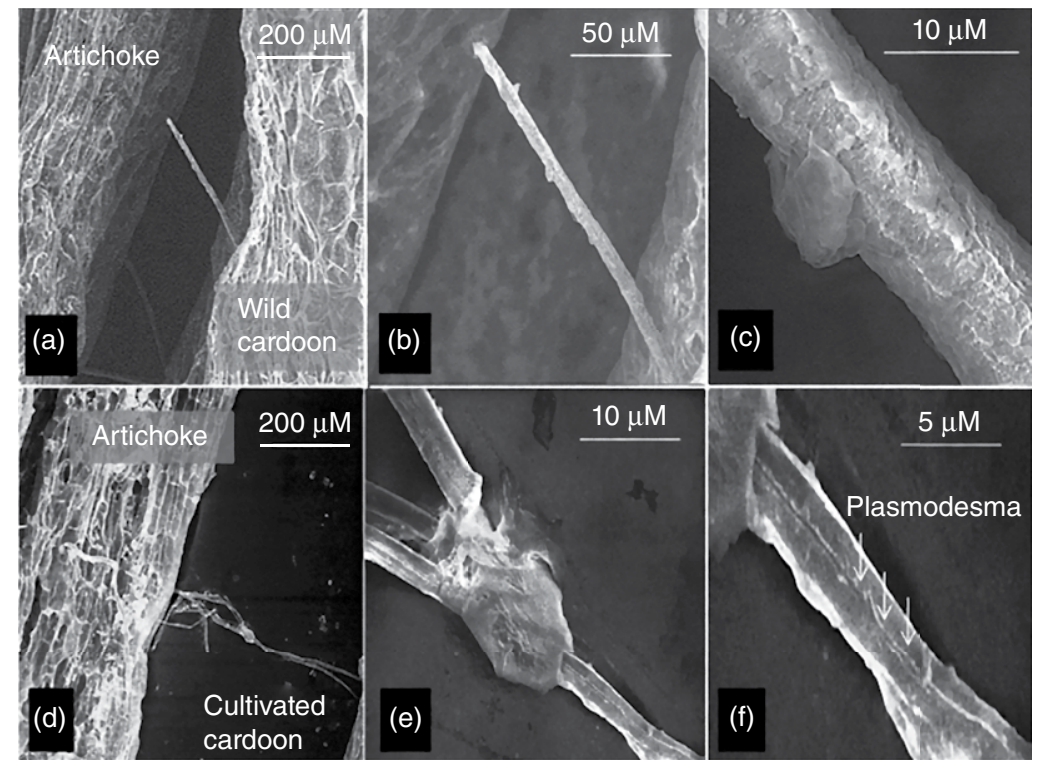

Fig. 5.2. Scanning electron microscopy variable pressure images of interconnections between artichoke-wild cardoon (a-c) and artichoke-cultivated cardoon (d-f) graft combinations, at 3 DAG. (From Trinchera et al., 2013, with permission.)

(24 DAG). Incompatible grafts showed lower water uptake and root sugar concentration, increased $\mathrm{H}_{2} \mathrm{O}_{2}$ and superoxide levels, lower peroxidase and superoxide dismutase (SOD) activities (Aloni et al., 2008) and a decrease in the photosynthetic activity in the grafting zone (Calatayud et al., 2013). Practical information related to vegetable graft compatibility is given in Table 5.1. Growth inhibition and high mortality were observed in severely incompatible grafted plants such as pepper-tomato and pepper-aubergine grafts at $21 \mathrm{DAG}$; this was associated with higher concentration of sugars and starch above compared with below the graft union (Kawaguchi et al., 2008). These observations were correlated with narrow and irregular xylem connections between the scion and rootstock (Kawaguchi et al., 2008). Similarly, in other vegetable crops (tomato, cabbage and radish) a necrotic, shrunken cell layer is formed in some areas at the graft interface at 3 DAG. The necrotic layer is formed from the collapsed cells and cytoplasmic remnants at the graft interface. Subsequently, some scion parenchyma cells adjacent to the necrotic layer start to divide along the inner surface of the wounded tissues, generating the callus. This cell proliferation process is strongly influenced by the grafting compatibility. In fact, in homografting, the necrotic layer disappears at the moment of cell division in correspondence with the callus formation, while, in incompatible grafting (as in Arabidopsis-tomato grafts), the necrotic layer seems to directly or indirectly inhibit the vascular tissue differentiation, thus blocking full vascular graft union formation between the two graft partners (Flaishman et al., 2008). In addition, the relationship between necrotic layer dissolution and grafting compatibility was evaluated by measuring the electrical resistance at the graft junction in compatible-incompatible combinations. In compatible 
Table 5.1. Graft compatibility from different vegetable rootstock-scion combinations

\begin{tabular}{|c|c|c|c|c|}
\hline Scion & Rootstock & $\begin{array}{l}\text { Rootstock } \\
\text { advantages }\end{array}$ & Compatibility & Reference \\
\hline Melon 'Arava' & $\begin{array}{l}\text { Pumpkin hybrid } \\
\text { genotype RS59 }\end{array}$ & $\begin{array}{l}\text { Fusarium } \\
\quad \text { resistance }\end{array}$ & Compatible & $\begin{array}{l}\text { Edelstein et al. } \\
\quad(2004)\end{array}$ \\
\hline Melon 'Arava' & $\begin{array}{l}\text { Pumpkin hybrid } \\
\text { genotype RS62 }\end{array}$ & $\begin{array}{l}\text { Fusarium } \\
\text { resistance }\end{array}$ & Incompatible & $\begin{array}{l}\text { Edelstein et al. } \\
\quad(2004)\end{array}$ \\
\hline $\begin{array}{l}\text { Pepper 'Scotch } \\
\text { Bonnet' }\end{array}$ & $\begin{array}{l}\text { Aubergine 'Black } \\
\text { Beauty' }\end{array}$ & Salt tolerant & High compatibility & $\begin{array}{l}\text { Ives et al. } \\
\text { (2012) }\end{array}$ \\
\hline $\begin{array}{l}\text { Pepper 'Scotch } \\
\text { Bonnet' }\end{array}$ & Tomato 'Akash' & Salt tolerant & $\begin{array}{l}\text { Moderate } \\
\text { compatibility }\end{array}$ & $\begin{array}{l}\text { Ives et al. } \\
\text { (2012) }\end{array}$ \\
\hline $\begin{array}{l}\text { Pepper 'Scotch } \\
\text { Bonnet' }\end{array}$ & $\begin{array}{r}\text { Solanum nigrum } \\
\text { (bitter gumma) }\end{array}$ & Salt tolerant & Low compatibility & $\begin{array}{l}\text { Ives et al. } \\
\text { (2012) }\end{array}$ \\
\hline Tomato 'Roma' & $\begin{array}{l}\text { Pepper 'Long Red } \\
\text { Cayenne' }\end{array}$ & $\begin{array}{l}\text { Disease } \\
\text { resistance }\end{array}$ & $\begin{array}{l}\text { Severely } \\
\text { incompatible }\end{array}$ & $\begin{array}{l}\text { Kawaguchi } \\
\text { et al. (2008) }\end{array}$ \\
\hline Tomato 'Roma' & $\begin{array}{l}\text { Aubergine 'Market } \\
\text { Supreme' }\end{array}$ & $\begin{array}{l}\text { Disease } \\
\quad \text { resistance }\end{array}$ & $\begin{array}{l}\text { Moderately } \\
\text { incompatible }\end{array}$ & $\begin{array}{l}\text { Kawaguchi } \\
\text { et al. (2008) }\end{array}$ \\
\hline $\begin{array}{l}\text { Pepper 'Dous } \\
\text { des Landes' }\end{array}$ & $\begin{array}{l}\text { Tomato } \\
\text { 'Saint Pierre' }\end{array}$ & $\begin{array}{l}\text { Disease resistant } \\
\text { radicular } \\
\text { system }\end{array}$ & Compatible & $\begin{array}{l}\text { Deloire and } \\
\text { Hébant } \\
(1982)\end{array}$ \\
\hline $\begin{array}{l}\text { Pepper } \\
\text { 'Yollowonder' } \\
\text { and 'Floridae' }\end{array}$ & $\begin{array}{l}\text { Tomato } \\
\text { 'Saint Pierre' }\end{array}$ & $\begin{array}{l}\text { Disease resistant } \\
\text { radicular } \\
\text { system }\end{array}$ & Incompatible & $\begin{array}{l}\text { Deloire and } \\
\text { Hébant } \\
(1982)\end{array}$ \\
\hline $\begin{array}{l}\text { Artichoke } \\
\text { 'Romolo' }\end{array}$ & $\begin{array}{l}\text { Wild cardoon } \\
\text { 'Sardo' }\end{array}$ & $\begin{array}{l}\text { Resistance to } \\
\text { Verticillium }\end{array}$ & High compatibility & $\begin{array}{l}\text { Trinchera et al. } \\
\text { (2013) }\end{array}$ \\
\hline $\begin{array}{l}\text { Artichoke } \\
\text { 'Romolo' }\end{array}$ & $\begin{array}{l}\text { Cultivated } \\
\text { cardoon 'Belgio' }\end{array}$ & $\begin{array}{l}\text { Resistance to } \\
\text { Verticillium }\end{array}$ & $\begin{array}{l}\text { Moderate } \\
\text { compatibility }\end{array}$ & $\begin{array}{l}\text { Trinchera et al. } \\
\text { (2013) }\end{array}$ \\
\hline Artichoke 'Istar' & $\begin{array}{l}\text { Cultivated cardoon } \\
\text { 'Bianco avorio' }\end{array}$ & $\begin{array}{l}\text { Resistance to } \\
\text { Verticillium }\end{array}$ & High compatibility & $\begin{array}{l}\text { Temperini et al. } \\
\text { (2013) }\end{array}$ \\
\hline Artichoke 'Istar' & $\begin{array}{l}\text { Wild cardoon } \\
\text { 'Sardo' }\end{array}$ & $\begin{array}{c}\text { Resistance to } \\
\text { Verticillium }\end{array}$ & Low compatibility & $\begin{array}{l}\text { Temperini et al. } \\
\text { (2013) }\end{array}$ \\
\hline Pepper 'Adige' & $\begin{array}{l}\text { Pepper (Capsicum } \\
\text { annuum) 'Serrano' }\end{array}$ & $\begin{array}{l}\text { Salt and drought } \\
\text { resistance }\end{array}$ & Low compatibility & $\begin{array}{l}\text { Penella et al. } \\
\text { (2013) }\end{array}$ \\
\hline Pepper 'Adige' & $\begin{array}{l}\text { Pepper (Capsicum } \\
\text { baccatum) } \\
\text { 'BOL-558' }\end{array}$ & $\begin{array}{l}\text { Salt and drought } \\
\text { resistance }\end{array}$ & $\begin{array}{l}\text { High-moderately } \\
\text { compatibility }\end{array}$ & $\begin{array}{l}\text { Penella et al. } \\
\quad(2015)\end{array}$ \\
\hline
\end{tabular}

scion-rootstock grafts, the electrical resistance increases rapidly with the necrotic layer development in the first $3 \mathrm{DAG}$ and then steadily decreases from 3 to $8 \mathrm{DAG}$ due to callus proliferation. Callus proliferation leads to the breakdown of the necrotic layer, formation of secondary plasmodesmata between adjacent scion-rootstock cells and the differentiation of vascular elements in the callus. Nevertheless, in incompatible grafting combinations, such as amaranth-tomato grafts, the electrical resistance at the graft junction remained high, because of the persistence of the necrotic layer (Yang et al., 1992). Furthermore, the incompatibility is evident through the lethal cellular senescence at the grafting surface, characterized by cell-wall suberization, vesiculation of the cytoplasm, degeneration of cellular organelles, loss of membrane integrity and, finally, death and collapse of the cell. 
In comparison with vegetable grafts, in which there is a high percentage of failure of successful grafts or where premature death of the graft union take place, in some fruit tree grafts, the incompatibility is characterized by anatomical alterations in the graft union area, which do not prevent the initial growth of the tree during the first few years. After callus cell proliferation at the graft interface, the differentiation of new cambial cells does not take place to the same extent in compatible and incompatible grafts, where some of the callus remains undifferentiated and becomes parenchymatous tissue. These parenchymatous regions intermingle with vascular tissue, and the union that occurs is mechanically weak, which causes the subsequent failure of the graft union due to a defective structural development (Errea et al., 1994a). In pear-quince (Ermel et al., 1997, 1999), apricot-peach and apricot-plum combinations (Errea et al., 1994a), incompatibility is caused by limited and/or not fully functional vascular reconnection between the scion and rootstock at the graft interface. In other combinations, some biochemical influence moves across the graft interface, causing phloem degeneration, and consequently carbohydrate movement from the scion to the rootstock is restricted at the graft union. In some peach-plum combinations, incompatibility appears generally during the beginning of the first summer after grafting (Zarrouk et al., 2006), and is expressed by tree growth cessation and premature tree defoliation (Moing et al., 1987). Alternatively, delayed incompatibility has been described in Prunus avium-Prunus cerasus grafts that failed after a period of years of apparently successful growth (Andrews and Serrano-Marquez, 1983; Hartmann and Kester, 1983; Treutter and Feucht, 1988). This delayed incompatibility is often foreshadowed by one or more typical symptoms developing prior to tree mortality (Webster and Schmidt, 1996). Sweet cherry scions showing incompatibility with P. cerasus rootstocks formed less phloem, the sieve plate had narrower pores and a high proportion of these pores were blocked with callose when compared with fully compatible grafts (Webster and Schmidt, 1996). Such responses, however, are based on translocation and thus could still be classified as translocated incompatibility.

\subsubsection{Translocation between grafted partners}

Grafted plants may show increased uptake of water and minerals compared with self-rooted plants as a consequence of the vigorous root system selected as a rootstock. The vascular connections at the scion-rootstock interface may determine water and nutrient translocation (Martínez-Ballesta et al., 2010). The investigation of water relations by hydraulic conductance $(K)$ measurements can indicate the water status of grafted plants. In tomato grafts, the gradual increase of $K$ from 4 to 8 DAG indicated the establishment of new vascular connections (Turquois and Malone, 1996; Fernández-García et al., 2004). K measurements below and above the graft union gave similar values in various grafted vegetables, suggesting that the graft union is not necessarily a barrier to water passage for a compatible scionrootstock combination (Martínez-Ballesta et al., 2010). Hence, the graft union may act like a continuous unit with respect to water movement. Regarding nutrient uptake, different authors have related the physical characteristics of the root system (lateral and vertical development) to attributes for enhancing the mineral content 
of the shoot (Jang, 1992; Penella et al., 2015). In graft union development, the formation of sieve-tube connections and symplastic continuity of sieve tubes are prerequisites for effective assimilate translocation from the scion to the rootstock (Schöning and Kollmann, 1997). Studies on phloem translocation of $\left[{ }^{14} \mathrm{C}\right]$ sucrose showed effective translocation across the graft interface in compatible graft unions (tomato-potato) correlating with the increasing numbers of sieve-tube connections, but this was not observed in incompatible grafts (faba bean-sunflower), suggesting apoplastic transport (Schöning and Kollmann, 1997).

Different compatibility/incompatibility mechanisms have been proposed, with special reference to the possibility that a phenomenon of cellular recognition must occur as part of adhesion and the events that follow in successful graft union formation (Moore and Walker, 1981; Jeffree and Yeoman, 1983). In grafts of cucumber-squash, it has been suggested that changes in protein banding may be due to polypeptides migrating symplastically across the graft union via the connecting phloem in such a way that translocation of signalling molecules, such as polypeptides in the phloem, could be significant in cell recognition and compatibility between the graft partners (Tiedemann and Carsens-Behrens, 1994). Indeed, a long-distance protein, mRNA and small RNA graft-transmissible signals are currently emerging as novel mechanisms to regulate nutritional and developmental root-shoot relationships and may play a pivotal role in grafting physiology (Goldschmidt, 2014). However, as yet there is no evidence for a specific biochemical or immunological recognition/rejection mechanism between the graft components.

\subsection{Role of Secondary Metabolites at the Interface in Graft Incompatibility}

When pear cultivars are grafted on to quince rootstocks, a cyanogenic glycoside, prunasin, which is normally found in quince but not in pear, is translocated into the pear phloem. Pear tissues breakdown the prunasin with a glycosidase, which liberates toxic hydrocyanic acid at the graft interface. The presence of cyanide causes the death of cells and destroys xylem and phloem tissues at the graft interface (Gur et al., 1968). However, the presence of cyanogenic glycosides in woody plants is restricted to relatively few genera, and this reaction cannot be considered as a universal cause of graft failure.

The effect of grafting on the content of phenolic compounds in graft unions marked by differing degrees of compatibility has been investigated in many species, and relationships between scion-rootstock compatibility and phenolic acid accumulation have been demonstrated (Errea, 1998; Usenik et al., 2006; Hudina et al., 2014; Canas et al., 2015). Phenolic compounds constitute a distinctive and unique group of plant metabolites that play important roles in higher plants. They participate in the structure of the plants and are involved in a great number of metabolic pathways (Vermerris and Nicholson, 2006; Lattanzio et al., 2008). These compounds are synthesized by plants in response to physical injury or under the influence of several biotic and abiotic stress situations (Treutter, 2006). Orchard management can also modify the phenol content of plant tissues 
(Mikulic-Petkovsek et al., 2010), in addition to differences linked to their developmental stage (Usenik et al., 2006).

Diverse phenolic compounds have been implicated in processes of division, development and differentiation into new tissues. These processes are involved in the usual sequence of events in the healing of a graft union (Errea, 1998; Hartmann et al., 2002). Therefore, phenolic compounds could be implicated during the steps of incompatible graft establishment causing insufficient callus proliferation, cell necrosis and accumulation of certain metabolites (Errea, 1998). Feucht et al. (1988) noticed that prunin application to Prunus callus cultures affected growth and cellular differentiation and initiated proanthocyanidin accumulation. Some studies have also shown quantitative and qualitative differences in the accumulation of phenols at the graft interface of different scion-rootstock combinations. It has been suggested that these metabolites are associated with different degrees of compatibility (Errea et al., 2001; Usenik et al., 2006; Mng'omba et al., 2008; Hudina et al., 2014). When graft unions are established between two different genotypes, physiological disorders may appear at the graft interface (Feucht and Treutter, 1991). In Prunus combinations, the biochemical basis for this assumption is that the phenolic compounds produced by heterospecific Prunus graft partners are quantitatively and qualitatively different (Geibel and Feucht, 1991; Errea et al., 1994b), and that a steep gradient is therefore established at the line of the union. Among the numerous polyphenols found in nature, proanthocyanidins or condensed tannins (oligomers and polymers composed of elementary flavan-3-ol units) are considered the second most abundant group of natural phenolics after lignins (He et al., 2008). These polyphenols are not only involved in normal processes of stress and wounding but can also play a prominent role in graft union formation by influencing lignification processes and inhibiting auxin transport, and by their protein-precipitating features (Lockard and Schneider, 1981; Hagerman, 2012), consequently impairing a good grafting union.

The effect of grafting on the content of phenolic compounds in graft unions marked by differing degrees of compatibility has been investigated by several lines of research, which found that the relationships between the scion and rootstock are affected by phenol accumulation. Elevated production of phenylpropanoid metabolites is a well documented fact in graft-incompatible combinations from different species, such as apricot (Errea et al., 1992; Usenik et al., 2006; Pina and Errea, 2008a), plum (Rodrigues et al., 2002; Zarrouk et al., 2010), cherry (Gebhardt and Feucht, 1982), pear (Musacchi et al., 2000; Hudina et al., 2014), loquat (Mng'omba et al., 2008), eucalyptus (de Cooman et al., 1996) and grapevine (Canas et al., 2015) grafted on to different rootstocks. The large number of incompatible scion-rootstock combinations with quantitative alterations in the phenolic compound profiles at the graft interface suggests that this is a conserved marker of graft incompatibility. According to Musacchi et al. (2000), compounds potentially more suited as indicators of graft incompatibility are in general those found in both scion and rootstock and also accumulate at the graft interface. In apricot, accumulation of monomeric and oligomeric flavan-3-ol compounds were related to problems in the differentiation of the callus (Errea et al., 1994b) and disorganization at the subcellular level (Errea et al., 1994a). The presence of phenolic compounds is generally associated with small cells in incompatible 
combinations, which do not differentiate and form successful unions (Errea et al., 2001) (see Plate 9). Similarly, the flavanol monomers (-)-epicatechin and (+)-catechin and the dimer procyanidin B2 showed the highest graft interface concentration in incompatible quince (Musacchi et al., 2000) and apricot-plum combinations (Errea et al., 2000). More recent studies also performed on pearquince combinations indicated that not only catechin and procyanidin B1 but also arbutin and several flavonols could be associated with graft incompatibility (Hudina et al., 2014). By analogy with incompatible fruit tree grafts, an abnormal phenolic accumulation (gallic, ellagic, gentisic, $p$-coumaric acid and (+)-catechin) in the graft interface zone could represent the first wound-induced response at the graft unions of incompatible micrografted Eucalyptus gunnii (de Cooman et al., 1996). Catechins have been reported to reduce or block stress-induced lipid peroxidation of the membranes (Gadkari and Balaramana, 2015; Martínez-Ballesta et al., 2010). Obviously, flavanols can be considered to form part of a complex fail-safe system that is active under highly oxidative and deleterious conditions occurring in stressed tissues (Elstner et al., 1994). Furthermore, regarding the mechanical stability of the union observed in Prunus and Pyrus combinations, a role has been proposed for a number of phenolics such as cinnamic acid derivatives or proanthocyanidins as cross-linking and cell-wall-stabilizing compounds (Pizzi and Cameron, 1986). Likewise, in response to grafting, the scion-rootstock interface of incompatible Arabidopsis-tomato grafts was composed of a dark red enriched material, similar to polyphenols. It appeared that this material may have restricted, or at least been involved in, preventing vascular bridge formation between the two species, a typical incompatibility response (Flaishman et al., 2008). Taken as a whole, most authors have reported that a significant accumulation of (+)-catechin above the graft union could be used as a biochemical marker of graft incompatibility (Errea, 1998; de Cooman et al., 1996; Musacchi et al., 2000; Usenik et al., 2006; Hudina et al., 2014; Canas et al., 2015).

Phenolic compounds interact with endogenous oxidative enzymes and are subject to rapid oxidation and further polymerization. In situations of graft incompatibility, polyphenols may escape from the vacuolar compartment into the cytoplasm due to loss of vacuolar membrane integrity by alteration of lipid peroxidation. Phenolics released from the vacuole into the cytosol are oxidized by peroxidases and polyphenol oxidases (Errea, 1998). The quinones and the polymers originated by these reactions can then interact with proteins, and as a consequence, grafting may be totally unsuccessful. In this respect, it is interesting to mention the importance of peroxidase and polyphenol oxidases in grafting incompatibility in trees. The peroxidase enzyme activity is associated with differentiating xylem (Sterjiades et al., 1993), as well as with lignification processes (Harkin and Obst, 1973), and it was demonstrated that higher peroxidase activity at the graft interface was related to graft incompatibility in Prunus sp. (Rodrigues et al., 2002) and peach-plum combinations (Zarrouk et al., 2010), as well as in incompatible E. gunnii micrografts (de Cooman et al., 1996). It was also suggested that differences in peroxidase isozyme banding patterns between the rootstock and scion may be the cause of bad vascular connections (Santamour, 1992). Some findings have also revealed that so-called monophenols stimulate indole-3-acetic acid (IAA) oxidases such as naringenin-7-glucoside (prunin), which accumulates above the graft union of 
incompatible P. avium-P. cerasus graftings (Treutter et al., 1985, 1986) and may destroy auxin (Feucht et al., 1983). Moreover, other studies working with tomato reported that peroxidase activity is implicated in the grafting process and that the enzyme was located mainly in the graft region (Fernández-García et al., 2004).

\subsection{Cell-to-cell Communication Between Graft Partners}

\subsubsection{Plant growth regulator and graft union formation}

In recent decades, there has been substantial progress in understanding hormonal signalling processes in graft communication during wound healing and vascular regeneration (reviewed by Chen et al., 2014). Plant hormones are important endogenous factors that play an important role in scion-rootstock communication (reviewed by Aloni et al., 2010). Several lines of evidence suggest that indole acetic acid (IAA) (the predominant auxin in higher plants) undergoes both an active, polar transport from cell to cell through whole plants and plant organs and long-distance translocation in the xylem and phloem systems (Benjamins and Scheres, 2008). In normal development, auxin is synthesized in shoot apical tissues and is actively transported towards the base of the plant, where it affects root development, morphology and functioning (Aloni, 1995; Lomax et al., 1995; Yin et al., 2012; Wang et al., 2014; Spiegelman et al., 2015). For example, the failure of auxin to cross the graft interface in the case of dwarfing rootstocks in apple leads to reduced rootstock xylem formation and hence a poor supply of water and minerals to the scion, producing the dwarfing effect (Lockard and Schneider, 1981; Soumelidou et al., 1994).

Several studies have further highlighted the role of auxin in controlling graft union development and graft incompatibility processes in different species. Auxin translocation from the scion to the rootstock was found to accelerate the formation of a successful graft in cactus (Shimomura and Fujihara, 1977). Working with interspecific Cucurbita spp. rootstocks with differential compatibilities when grafted with melon, Aloni et al. (2008) proposed that the main cause of graft incompatibility is the occurrence of hormonal imbalance, primarily of auxin and ethylene, in the root system following the establishment of the grafting connections. This study supported the notion that auxin produced in the scion is translocated downwards to the root after the grafting connection is established, and that when reaching a threshold concentration, auxin triggers degradative processes, causing root decay in the incompatible pumpkin rootstock. Furthermore, several reports have suggested that root inhibition by high auxin concentrations may be caused by auxin-induced ethylene production (Mulkey et al., 1982; Rahman et al., 2001). As shown by Aloni et al. (2010), incompatibility may result from basipetal auxin transport to the rootstock where it induces ethylene production and oxidative stress. In compatible grafting, antioxidative mechanism(s) may be activated, reducing oxidative stress in the root and enabling its growth. Exogenous application of IAA transport blockers, abscisic acid, anti-ethylene agents or compounds with antioxidant properties may reduce grafting incompatibility. 
Genomics studies have identified genes with defined functions in either auxin influx or efflux differentially expressed during graft union development. Several authors have highlighted the role of auxin at early stages of graft union formation in Arabidopsis (Yin et al., 2012; Wang et al., 2014), and Cookson et al. (2013) identified the induction of one gene encoding an auxin influx carrier at 3 DAG in the graft interface zone of grapevine. Recently, transcriptomic analysis using hypocotyl micrografting in Arabidopsis described the stages of graft union development and suggested a role for cell-to-cell communication processes during the early stages (Yin et al., 2012). In this study, activation of the ethylene and jasmonic acid biosynthesis pathways and the stimulus-response categories at 1 DAG confirmed that plants utilized the wound-induced programme to accomplish successful graft union formation. Nevertheless, a complete understanding of the hormonal control of grafting success is far from complete (Aloni et al., 2010).

\subsubsection{Cell-to-cell communication at the graft interface}

It is known that, before the scion can become dependent on the rootstock in grafted plants, cellular contact must be established to enable the formation of a symplasmic and apoplasmic transport system between the graft partners. One factor that contributes to a successful vegetable or fruit tree graft is the establishment of symplastic cell connections, which facilitate the transfer of compounds between the scion and rootstock (Hartmann et al., 2002). Increasing evidence indicates that cell recognition and direct cellular communication between the callus of the scion and the rootstock is crucial for grafting success (Jeffree and Yeoman, 1983; Kollmann et al., 1985; Pina et al., 2009, 2012; Yin et al., 2012; Trinchera et al., 2013). During grafting, plasmodesmata, one of the main communication pathways, are formed de novo across existing cell walls between opposing surfaces of the scion and rootstock (Kollmann and Glockmann, 1991; Yang et al., 1992). Research on the mechanisms of plasmodesmata formation have shown differences in the development of interspecific plasmodesmata between graft partners, suggesting that cell recognition and functional coordination between the two different genotypes at the graft interface is involved in graft formation (Kollmann and Glockmann, 1985; Kollmann et al., 1985). One hypothesis on the development of rootstock-scion incompatibility is that a late rejection is predetermined at the initial step of callus contact. It has been shown that insufficient coordination between adjacent cells at the graft interface may lead to the formation of mismatching, half plasmodesmata in incompatible faba bean-sunflower heterografts (Kollmann et al., 1985). However, in compatible cucumber-figleaf gourd heterografts and tomato homografts, the wound response is followed by dissolution of the necrotic layer, a prerequisite to the formation of continuous secondary plasmodesmata between cells of both graft partners (Tiedemann, 1989; Yang et al., 1992). Late graft rejection in fruit trees has been associated with limited plasmodesmal coupling at the time of grafting within one of the partners (Pina et al., 2009). The problem of incompatibility in grafted Prunus spp. trees may be related to low intercellular transport capacity - a low size-exclusion limit or a low number of functional plasmodesmata - in either rootstock or scion callus tissues or between the two (Pina et al., 2009, 2012). In addition, Trinchera et al. (2013) 
confirmed de novo formation of many plasmodesmata between scions and rootstocks with high compatibility, particularly in the globe artichoke-wild cardoon combination. Overall, it has been proposed that a novel control factor of connectivity could reach the graft partner and changes its innate rate of communication. Furthermore, gene expression differences suggest the involvement of plasmodesmata in graft union success. The expression levels of plasmodesmata-located protein PDLP1A (AT5G43980) and AT2G41870 were elevated at early stages of development in Arabidopsis homografts (Yin et al., 2012). It is known that PDLP1A targets the plasmodesmata and participates in plasmodesmal trafficking (Thomas et al., 2008). These results also imply that plasmodesmata may contribute to cellto-cell communication in graft union development.

\subsection{Understanding the Molecular Mechanisms Involved in Graft Union Formation and Compatibility}

\subsubsection{Genes differentially expressed during graft union formation}

The cellular events at the graft interface have been well characterized by histological studies in woody (apple tree and Prunus spp., Soumelidou et al., 1994; Errea et al., 2001; Pina et al., 2009) and non-woody (Arabidopsis, Flaishman et al., 2008; artichoke, Trinchera et al., 2013) plants. However, the molecular mechanisms for graft union development are still largely unknown. In recent years, more attention has been paid to global changes in gene expression during the process of graft formation. Gene expression studies have been used to shed light on the mechanisms behind graft union development in various species. In homografts, the genes differentially expressed at the graft interface are presumably the same as those induced during wound-healing processes. cDNA-amplified fragment length polymorphism analysis was used to examine the gene expression in homografts of hickory (Carya cathayensis) at four time points (0, 3, 7 and 14 DAG) during graft union development (Zheng et al., 2010). In this study, the authors identified 49 genes differentially expressed during graft union formation in hickory and revealed that 19 genes of known function were involved in IAA transport, the cell cycle, signal transduction, water metabolism, nuclear metabolism, amino acid metabolism, protein metabolism, carbon metabolism and secretion of substances. Among these, 12 genes, potentially related to cambium formation and cell growth, were induced by grafting at the transcriptional level, suggesting that $C$. cathayensis undergoes a complex change in metabolism in the first 14 DAG. Similarly, graft union development in Arabidopsis hypocotyl micrografts has been studied recently at the transcriptional level at 1 DAG, which showed the involvement of wound and hormone signalling (Yin et al., 2012). A set of stimulus-response categories was significantly overrepresented, suggesting that a wound-induced programme was initiated in the graft union developmental processes. In a recent study, homografting of overwintering stems of grapevine resulted in the upregulation of many genes involved in cell-wall synthesis, wound responses, secondary metabolism, hormone signalling, and phloem and xylem development from 3 to 28 DAG (Cookson et al., 2013). Overlap of genes differentially expressed at the scion-rootstock interface and regulation 
of gene expression over time suggested that some similar processes may take place between the reactivation of stem growth in the spring and the graft union formation process (Cookson et al., 2013). However, the majority of genes differentially regulated in the graft interface were specific to graft union formation. In this sense, numerous graft interface-specific genes were identified as being associated with defence and wound responses, such as genes encoding MYB-like 102, germin-like proteins, peroxidases and chitinases (Cookson et al., 2013). In addition, graft union formation triggered the differential expression of transcription factors involved in the callus maintenance in the graft interface compared with the rootstock tissue, suggesting that callus formation requires considerable regulation at the transcriptional level. In particular, it was found that the LATERAL BOUNDARY DOMAIN 4 (LBD4) gene was induced at 3 DAG and could be related to the formation and maintenance of non-differentiated callus cells (Fan et al., 2012; Ikeuchi et al., 2013). In addition, a late embryogenesis abundant protein with structural similarity to animal fibronectin domain proteins was also induced (Cookson et al., 2013). Because fibronectins from animal cells have been shown to be involved in cell adhesion, motility, wound healing and maintenance of cell shape, these results potentially suggested a role in graft union formation (Singh et al., 2005).

In a later study, Cookson et al. (2014) identified many genes induced by grafting in two different grapevine genotypes (heterografts) in comparison with the wound-like gene expression changes in homografts during the first month after grafting. In general, heterografting triggered the differential expression of a large number of genes involved in plant defence and stress responses. Compared with homografting, heterografting resulted in the rapid induction of oxidative stress responses and pathogenesis-related proteins, and was followed by the induction of many other genes involved in plant stress responses (Fig. 5.3).

\section{Morphological changes}

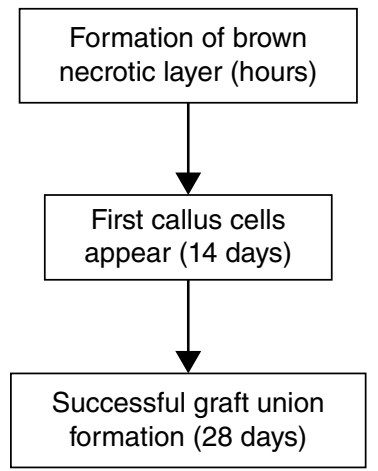

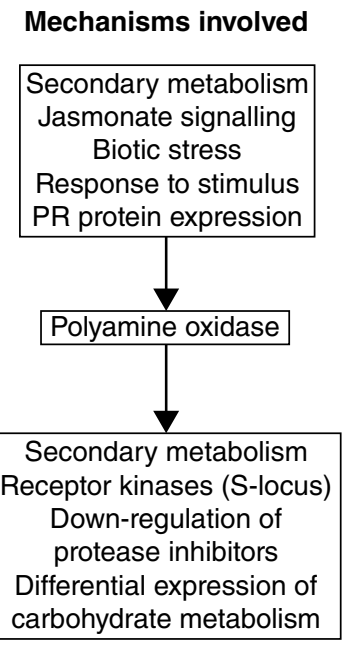

Fig. 5.3. Relationship between morphological changes and molecular mechanisms involved in grafting together two different genotypes. (From Cookson et al., 2014, with permission.) 
At this early stage of development, genes encoding enzymes involved in oxidative stress were also identified (e.g. glutathione $S$-transferases, ascorbate oxidase, polyphenol oxidases and peroxidases) and could be associated with the induction of an oxidative burst at the graft interface. By 7 and 14 DAG, the functional category polyamine oxidase was enriched, which has been shown to be one of the key elements for oxidative burst to induce programme cell death (Yoda et al., 2006). The sustained induction of many genes involved in secondary metabolism enzymes (cell-wall precursors, lignin and flavonol biosynthesis) and repression of protease kinases towards the end of graft union formation (14-28 DAG) were also observed (Cookson et al., 2014). This could suggest that the cells at the graft interface are able to sense the presence of an intraspecific or interspecific heterograft, which could trigger an immune-type response.

\subsubsection{Genes differentially expressed between compatible and incompatible graft combinations}

It is widely known that the more closely the plants are related botanically, the better the chances are for the graft union to be successful (Hartmann et al., 2002). Although graft incompatibility has been widely reported (reviewed by Hartmann et al., 2002; Pina and Errea, 2005; Goldschmidt, 2014), the molecular causes underlying graft incompatibility are not well known. Recent studies have indicated that as well as physiological and anatomical changes during graft formation, molecular changes may also be involved in generating different behaviours between compatible-incompatible combinations (Aloni et al., 2008; Pina and Errea, 2008a,b; Nocito et al., 2010; dos Santos Pereira et al., 2014; Irisarri et al., 2015). Most molecular studies have been conducted with fruit trees. In certain tree scion-rootstock combinations, incompatibility may appear several years after grafting (Errea et al., 2001; Zarrouk et al., 2010), whereas in herbaceous plants (e.g. Cucurbita spp.), apparently successful grafts may become incompatible at 24 DAG (Edelstein et al., 2004; Aloni et al., 2008).

Incompatibility between different genotypes has been associated with the induction of phenylalanine ammonia lyase (PAL) in in vitro callus unions. PAL expression was further increased by incompatible heterografts (apricot-plum) in comparison with both homograft controls (Pina and Errea, 2008a). Two isoforms of PAL have been identified in the genus Prunus (PAL1 and PAL2); the PAL1 isoform has a greater influence in the scion-rootstock incompatibility process (dos Santos Pereira et al., 2014). UDP-glucose pyrophosphorylase (UGPase) was also identified in Prunus spp. as a promising protein that could be related to the graft compatibility/incompatibility responses (Pina and Errea, 2008b). This protein is involved in sucrose metabolism and the biosynthesis of cell-wall polysaccharides, and it was found that UGPase mRNA transcript and enzyme activity levels were diminished in the rootstock from incompatible heterografts (apricot-plum) at early stages of graft development compared with the corresponding autografts (Pina and Errea, 2008b).

Oxidative stress has been also implicated in the grafting incompatibility response of herbaceous and woody plants (Aloni et al., 2008, Nocito et al., 2010; 
Irisarri et al., 2015). As the production of reactive oxygen species (ROS) is one of the primary and general events following wounding in higher plants (Slesak et al., 2008), coping with oxidative stress could be an important factor in achieving successful grafts. Although exposing plants to stress situations, such as grafting, would trigger the antioxidant defence systems, there are indications that, within incompatible scion-rootstock interfaces, either the level of ROS is increased or there is a less efficient detoxification system (Aloni et al., 2008; Irisarri et al., 2015). For instance, non-successful grafts show signs of cellular stress, such as high accumulation of $\mathrm{H}_{2} \mathrm{O}_{2}$, superoxide radicals $\left(\mathrm{O}_{2}^{-}\right)$and increases in the levels of 2-thiobarbituric acid reactive metabolites (Aloni et al., 2008; Nocito et al., 2010). Incompatible melon-aubergine combinations showed the lowest level of antioxidant enzymes (SOD and peroxidase) and higher levels of ROS at the graft interface than compatible grafts at 14 and $24 \mathrm{DAG}$, and could be responsible for degradation of the grafting zone (Aloni et al., 2008). At earlier stages of development, Nocito et al. (2010) reported that the activity of five antioxidant enzymes (ascorbate peroxidase (APX), dehydroascorbate reductase (DHR), glutathione reductase (GR), SOD and catalase (CAT)) was increased in incompatible pear-quince heterografts in comparison with the compatible pear-pear autografts after a 7-day co-culture period. In addition, specific isoforms of genes involved in oxidative stress were identified in pear-pear homografts and pear-quince heterografts. Genes differentially expressed between compatible and incompatible in vitro callus heterografts were identified. The transcript levels of six antioxidant genes (SOD1, SOD3, APX3, APX6, CAT1 and $C A T 3$ ) were repressed at $10 \mathrm{DAG}$ in the incompatible heterograft in comparison with the compatible graft (Irisarri et al., 2015). These results suggested decreased oxidative protection during the graft union development in the incompatible heterograft. It has been proposed that the oxidative stress symptoms may represent a belated response to the auxin imbalance (Aloni et al., 2010; Goldschmidt, 2014).

In summary, important metabolic pathways have been identified as responsible for physiological failure in graft-incompatible scion-rootstock combinations in different plant species, such as the phenylpropanoid and cell-wall biosynthesis pathways. A large number of genes have been associated with this agronomic trait, suggesting that the genetic control of graft (in)compatibility is complex. The establishment of plant models for various levels of graft incompatibility with Arabidopsis will facilitate the study of the fundamental cellular genetic and molecular aspects involved in this important agricultural trait to a greater extent than any other model system (Flaishman et al., 2008). Although not a crop, Arabidopsis may provide valuable insights into the genetic control of graft formation by allowing the identification of many genes and cellular processes involved in graft union formation and incompatibility (Flaishman et al., 2008; Yin et al., 2012).

\subsection{Methods for Examining Graft Union Development and Compatibility}

\subsubsection{In vitro techniques}

The use of tissue culture techniques may be an interesting approach to study compatibility/incompatibility phenomena, as the physiological and cellular responses 
of in vitro graft systems mimic those that occur in vivo, and could reduce drastically the amount of time and effort necessary for determining the compatibility response. In this sense, previous studies have shown that in vitro graft systems closely match in vivo graft systems, in both herbaceous grafts for tomato-potato (Wang and Kollmann, 1996) and faba bean-sunflower (Schöning and Kollmann, 1997) and fruit species (Richardson et al., 1996; Errea et al., 2001; Espen et al., 2005). These tissue culture techniques include in vitro shoot tip grafting, grafting of an explanted stem segment in vitro and callus grafting. In vitro shoot tip grafting, also called micrografting, consists of aseptically grafting a small shoot tip on to an in vitro rootstock seedling and is often used to produce virus-free plants. In vitro grafting methods using explanted stem segments consist of cutting a part of a plant stem into segments, grafting these together and culturing them in sterile medium. To establish callus grafts, or in vitro callus fusion, callus tissue is obtained from stem fragments cultured in vitro, and the grafts are established by making two clean-cut callus pieces and placing one on top of the other under sterile conditions in the same culture medium and conditions as used for callus initiation. Advances in micrografting methods for studying graft union formation have been particularly been done in Arabidopsis, as reported by Yin et al. (2012). This method facilitated sample analysis and yielded higher success rates than previous methods, and could easily be applied to other dicotyledonous plants, such as tomato, lucerne and tobacco.

As pointed out by Moore (1991), an incompatible response does not need to be associated with any particular stage of tissue development, as the incompatibility factor would be produced by 'ground tissues' such as callus or suspension cultures, and successful grafting of callus masses in vitro indicates that graft compatibility does not require the presence of more highly differentiated cells (Moore, 1983).

\subsubsection{Histological studies}

The cellular events at the graft interface have been well characterized by histological techniques in various herbaceous and woody plants from the study of plasmodesmata formation at the nanometer level to the macroscopic tissue organization of the callus (Soumelidou et al., 1994; Pina et al., 2009; Errea et al., 2001; Trinchera et al., 2013; Irisarri et al., 2015). Light and electron microscopy have given detailed information related to graft union formation in tomato autografts (Jeffree and Yeoman, 1983), pear-quince grafts (Ermel et al., 1997) and in artichoke (Trinchera et al., 2013) and apricot (Errea et al., 1994a, 2001) grafts, as well as in the model plant Arabidopsis (Flaishman et al., 2008). Scanning electron microscopy can be used effectively in anatomical studies on graft union development, without prior sample preparation, saving time and avoiding possible artefacts, which could be introduced with specimen preparation. Likewise, the development of confocal bioimaging tools constitutes a valuable non-invasive method to study plasmodesmal permeability in living tissues with high temporal and spatial resolution (Martens et al., 2004). Photoactivation and photobleaching techniques have been applied to study cell-to-cell communication via plasmodesmata in in vitro grown callus. It was demonstrated that callus cells in compatible and incompatible grafts differed 
in their ability to establish symplasmic connections (Pina et al., 2009, 2012). In addition, three-dimensional visualization of the graft interface using X-ray tomography has provided new insights into the spatial tissue organization of the graft interface in grapevine (Milien et al., 2012).

\subsubsection{Chlorophyll fluorescence imaging as a diagnostic technique}

Grafting causes stress in plants: mechanical wounding in the scion and rootstock results in localized cell death, loss of water and solutes, and disruption of the vascular system. The activation of repair mechanisms place a high metabolic demand on the grafting area to supply carbon skeletons, synthesize new molecules or increase antioxidative enzyme activity (Fernández-García et al., 2004; Pina and Errea, 2005; Aloni et al., 2008). Many of these processes can be supported by photosynthetic activity (Calatayud et al., 2013). Information on changes in the efficiency of photochemistry can be obtained by measuring and visualizing the yield of chlorophyll $a$ fluorescence (Maxwell and Johnson, 2000). Variations in fluorescence parameters can be visualized through images that reveal spatial-temporal changes in grafted plants using imaging fluorometers, which provide a quick and non-invasive technique. This method has been validated in grafted melon plants (Calatayud et al., 2013), where compatibility/incompatibility studies were performed using melon cultivars ('Ricura' (R) and 'Sancho' (S), Cucumis melo var. saccharinus) grafted on to Cucurbita maxima $\times$ Cucurbita moschata ('Shintoza' (SH)). Yield production showed than SH-S plants had higher compatibility than SH-R plants. The Fv/Fm ratio, which is proportional to the maximal quantum yield of photosystem II photochemistry, was a good indicator of compatibility degree. The values of the Fv/Fm ratio images were higher in $\mathrm{SH}-\mathrm{S}$ than in SH-R plants at 10 and 15 DAG (Calatayud et al., 2013) (see Plate 10). These studies showed that chlorophyll fluorescence imaging allows diagnosis of compatibility or incompatibility at an earlier phase after grafting.

\subsection{Conclusions}

Plant grafting is a widely used means of plant propagation, especially in fruit trees but also in vegetables, where the purpose is to add value to the elite varieties by improving different traits. It is of considerable importance in the deployment and regional adaptation of elite cultivars, but its range of application is restricted by anatomical, physiological and biochemical aspects that produce incompatible grafts. Graft incompatibility is a general phenomenon in many vegetable and woody species, and is a factor that makes rootstock and cultivar selection difficult, as the introduction of some new varieties requires knowledge of the extent and nature of incompatibility reactions. In this sense, early detection of graft compatibility substantially aids cultivar and rootstock breeding selection.

Some authors have reported that many anatomical and physiological changes are produced during the early graft development of compatible and incompatible unions. However, there is limited information on the molecular and 
cellular recognition mechanisms of incompatibility. Recently, genes known to be involved in wounding/healing, vascular differentiation, programmed cell death, ROS production/elimination, phenylpropanoid pathways and cell-wall biosynthesis, have been identified during graft union development and graft incompatibility reactions. More research is needed to investigate how to overcome graft incompatibility. The use of auxins, ethylene blockers, abscisic acid or its analogues, gibberellins and compounds with antioxidation properties, as well as inhibitors of enzymes involved in the phenylpropanoid pathway, are all candidates of interest.

\section{References}

Aloni, R. (1995) The induction of vascular tissues by auxin and cytokinin. In: Davies, P.J. (ed.) Plant Hormones: Physiology, Biochemistry and Molecular Biology, 2nd edn. Kluwer Academic Publishers, Dordrecht, The Netherlands, pp. 531-546.

Aloni, B., Karni, L., Deventurero, G., Levin, Z., Cohen, R., Katzir, N., Lotan-Pompan, M., Edelstein, M., Aktas, H., Turhan, E., Joel, D.M., Horev, C. and Kapulnik, Y. (2008) Physiological and biochemical changes at the rootstock-scion interface in graft combinations between Curcurbita rootstocks and melon scion. Journal of Horticultural Science and Biotechnology 83, 777-783.

Aloni, B., Cohen, R., Karni, L., Aktas, H. and Edelstein, M. (2010) Hormonal signaling in rootstock-scion interactions. Scientia Horticulturae 127, 119-126.

Andrews, P.K. and Serrano-Marquez, C. (1993) Graft incompatibility. Horticultural Reviews 15, 183-231.

Benjamins, R. and Scheres, B. (2008) Auxin: the looping star in plant development. Annual Review of Plant Biology 59, 443-465.

Calatayud, A., San Bautista, A., Pascual, B., Maroto, J.V. and López-Galarza, S. (2013) Use of chlorophyll fluorescence imaging as diagnostic technique to predict compatibility in melon graft. Scientia Horticulturae 149, 13-18.

Canas, S., Assunção, M., Brazão, J., Zanol, G. and Eiras-Dias, J.E. (2015) Phenolic compounds involved in grafting incompatibility of Vitis spp: development and validation of an analytical method for their quantification. Phytochemical Analysis 26, 1-7.

Chen, J.J., Zhang, J. and He, X.Q. (2014) Tissue regeneration after bark girdling: an ideal research tool to investigate plant vascular development and regeneration. Physiologia Plantarum 151, 147-155.

Cookson, S.J., Clemente-Moreno, M.J., Hevin, C., Nyamba-Mendome, L.Z., Delrot, S., TrossatMagnin, C. and Ollat, N. (2013) Graft union formation in grapevine induces transcriptional changes related to cell wall modification, wounding, hormone signalling, and secondary metabolism. Journal of Experimental Botany 64, 2997-3008.

Cookson, S.J., Clemente-Moreno, M.J., Hevin, C., Nyamba-Mendome, L.Z., Delrot, S., Magnin, N., Trossat-Magnin, C. and Ollat, N. (2014) Heterografting with nonself rootstocks induces genes involved in stress responses at the graft interface when compared with autografted controls. Journal of Experimental Botany 65, 2473-2481.

Deloire, A. and Hébant, C. (1982) Peroxidase activity and lignifications at the interface between stock and scion of compatible and incompatible grafts of Capsicum on Lycopersicon. Annals of Botany 49, 887-891.

de Cooman, L., Everaert, E., Curir, P. and Dolci, M. (1996) The possible role of phenolics in incompatibility expression in Eucalyptus gunnii micrografts. Phytochemical Analysis 7 , 92-96. 
dos Santos Pereira, I., da Silva Messias, R., Diniz Campos, A., Errea, P. and Pina, A. (2014) Growth characteristics and phenylalanine ammonia-lyase activity in peach grafted on different Prunus spp. Biologia Plantarum 58, 114-120.

Edelstein, M., Burger, Y., Horev, C., Porat, A., Meir, A. and Cohen, R. (2004) Assessing the effect of genetic and anatomic variation of Cucurbita rootstocks on vigour, survival and yield of grafted melons. Journal of Horticultural Science and Biotechnology 79, 370-374.

Elstner, E.F., Osswald, W., Volpert, R. and Schempp, H. (1994) Phenolic antioxidants. Acta Horticulturae 381, 304-335.

Ermel, F.F., Poëssel, J.L., Faurobert, M. and Catessons, A.M. (1997) Early scion/stock junction in compatible and incompatible pear/pear and pear/quince grafts: a histocytological study. Annals of Botany 79, 505-515.

Ermel, F.F., Kervella, J., Catesson, A.M. and Poëssel, J.L. (1999) Localized graft incompatibility in pear/quince (Pyrus communis/Cydonia oblonga) combinations: multivariate analysis of histological data from 5-month-old grafts. Tree Physiology 19, 645-654.

Errea, P. (1998) Implications of phenolic compounds in graft incompatibility in fruit tree species. Scientia Horticulturae 74, 195-205.

Errea, P., Treutter, D. and Feucht, W. (1992) Specificity of individual flavan-3-ols interfering with the grafting stress of apricots. Angewandte Botanik 66, 21-24.

Errea, P., Felipe, A. and Herrero, M. (1994a) Graft establishment between compatible and incompatible Prunus spp. Journal of Experimental Botany 45, 393-401.

Errea, P., Treutter, D. and Feucht, W. (1994b) Characterization of flavanol type-polyphenols in apricot cultivar and rootstocks. Advances in Horticultural Science 8, 165-169.

Errea, P. Gutmann, M. and Feucht, W. (2000) Physiological implications of flavan-3-ols in apricot-rootstock combinations. Advances in Horticultural Science 14, 126-134.

Errea, P., Garay, L. and Marin, J.A. (2001) Early detection of graft incompatibility in apricot (Prunus armeniaca) using in vitro techniques. Physiologia Plantarum 112, 135-141.

Espen, L., Cocucci, M. and Sacchi, G.A. (2005) Differentiation and functional connection of vascularelements in compatible and incompatible pear/quince internode micrografts. Tree Physiology 25, 1419-1425.

Fan, M.Z., Xu, C.Y., Xu, K. and Hu, Y. (2012) LATERAL ORGAN BOUNDARIES DOMAIN transcription factors direct callus formation in Arabidopsis regeneration. Cell Research 22, 1169-1180.

Fernández-García, N., Carvajal, M. and Olmos, E. (2004) Graft union formation in tomato plants: peroxidase and catalase involvement. Annals of Botany 93, 53-60.

Feucht, W. and Treutter, D. (1991) Phenol gradients in opposing cells of Prunus heterografts. Advances in Horticultural Science 5, 107-111.

Feucht, W., Schmid, P.P.S. and Christ, E. (1983) Compatibility in Prunus avium/Prunus cerasus grafts during initial phase. II. Reduction of cell number and peroxidases in the rootstock cambium. Scientia Horticulturae 21, 225-231.

Feucht, W., Treutter, D. and Schmid, P.P.S. (1988) Inhibition of growth and xylogenesis and promotion of vacuolation in Prunus callus by the flavanone prunin. Plant Cell Report 7 , 189-192.

Flaishman, M.A., Loginovski, K., Golobowich, S. and Lev-Yadun, S. (2008) Arabidopsis thaliana as a model system for graft union development in homografts and heterografts. Journal of Plant Growth Regulation 27, 231-239.

Gadkari, P.V. and Balaramana, M. (2015) Catechins: sources, extraction and encapsulation: a review. Food and Bioproducts Processing 93, 122-138.

Gebhardt, K. and Feucht, W. (1982) Polyphenol changes at the union of Prunus avium/Prunus cerasus grafts. Journal of Horticultural Science 57, 253-258.

Geibel, M. and Feucht, W. (1991) Flavonoid 5-glucosides from Prunus cerasus bark and their characteristic weak glycosidic bonding. Phytochemistry 30, 1519-1521. 
Goldschmidt, E.E. (2014) Plant grafting, new mechanisms, evolutionary implications. Frontiers in Plant Science 5, 727.

Guan, W., Zhao, X., Hassel, R. and Thies, J. (2012) Defense mechanisms involved in disease resistance of grafted vegetables. HortScience 47, 164-170.

Gur, A., Samish, R.M. and Lifshitz, E. (1968) The role of cyanogenic glycoside of the quince in the incompatibility between pear cultivars and quince rootstocks. Horticultural Research 8, 113-134.

Hagerman, A.E. (2012) Fifty years of polyphenol-protein complexes. In: Cheynier, V., SarniManchado, P. and Quideau, S. (eds) Recent Advances in Polyphenol Research, Vol. 3. Wiley, Oxford, pp. 71-98.

Harkin, J.M. and Obst, T.R. (1973) Lignification in trees: indication of exclusive peroxidase participation. Science 180, 296-297.

Hartmann, H.T. and Kester, D.E. (1983) Plant Propagation. Principles and Practices, 4th edn. Prentice-Hall, London, pp. 726.

Hartmann, H.T., Kester, D.E., Davies, F.T. and Geneve, R.L. (2002) Plant Propagation. Principles and Practices, 7th edn. Prentice-Hall, Upper Saddle River, New Jersey.

He, F., Pan, Q.H., Shi, Y. and Duan, C.Q. (2008) Biosynthesis and genetic regulation of proanthocyanidins in plants. Molecules 13, 2674-2703.

Hudina, A., Orazen, M.,P., Jakopic, J. and Stampar, F. (2014) The phenolic content and their involvement in the graft incompatibility process of various pear rootstocks (Pyrus communis L.). Journal of Plant Physiology 171, 76-84.

Ikeuchi, M, Sugimoto, K. and Iwase1, A. (2013) Plant callus: mechanisms of induction and repression. Plant Cell 25, 3159-3173.

Irisarri, P., Binczycki, P., Errea, P., Martens, H.J. and Pina, A. (2015) Oxidative stress associated with rootstock-scion interactions in pear/quince combinations during early stages of graft development. Journal of Plant Physiology 176, 25-35.

Ives, L., Brathwaite, R., Barclay, G., Isaac, W.A. and Connor, C.B. (2012) Graft compatibility of scotch bonnet. Journal of Agricultural Science and Technology 2, 81-92.

Jang, K.U. (1992) Utilization of Sap and Fruit Juice of Luffa cylindrica L. Korean Ginseng and Tobacco Institute, Taejon, South Korea.

Jeffree, C.E. and Yeoman, M.M. (1983) Development of intercellular connections between opposing cells in a graft union. New Phytologist 93, 491-509.

Kawaguchi, M., Taji, A., Backhouse, D. and Oda, M. (2008) Anatomy and physiology of graft incompatibility in Solanaceous plants, Journal of Horticultural Science and Biotechnology 83, 581-588.

Kollmann, R. and Glockmann, C. (1985) Studies on graft unions. I. Plasmodesmata between cells of plants belonging to different unrelated taxa. Protoplasma 124, 224-235.

Kollmann, R. and Glockmann, C. (1991) Studies on graft unions. III. On the mechanism of secondary formation of plasmodesmata at the graft interface. Protoplasma 165, 71-85.

Kollmann, R., Yang, S. and Glockmann, C. (1985) Studies on graft unions. II. Continuous and half plasmodesmata in different regions of the graft interface. Protoplasma 126, 19-29.

Lattanzio, V., Kroon, P.A., Quideau, S. and Treutter, D. (2008) Plant phenolics - secondary metabolites with diverse functions. In: Daayf, F. and Lattanzio, V. (eds) Recent Advances in Polyphenol Research, Vol. 1. Wiley, Oxford, pp. 1-24.

Lee, J.M. (1994) Cultivation of grafted vegetables. I. Current status, grafting methods, and benefits. HortScience 29, 235-239.

Lee, J.M. and Oda, M. (2003) Grafting of herbaceous vegetable and ornamental crops. Horticultural Reviews 28, 61-124.

Lee, J.M., Kubota, C., Tsao, S.J., Bie, Z., Hoyos-Echevarria, P., Morra, L. and Oda, M. (2010) Current status of vegetable grafting: diffusion, grafting techniques, automation. Scientia Horticulturae 127, 93-105. 
Lockard, R.G. and Schneider, G.W. (1981) Stock and scion relationships and the dwarfing mechanism in apple. Horticultural Reviews 3, 315-375.

Lomax, T.L., Muday, G.K. and Rubery, P.H. (1995) Auxin transport. In: Davies, P.J. (ed.) Plant Hormones: Physiology, Biochemistry and Molecular Biology, 2nd edn. Kluwer Academic Publishers, Dordrecht, The Netherlands, pp. 509-530.

Martens, H.J., Hansen, M. and Schulz, A. (2004) Caged probes: a novel tool in studying symplasmic transport in plant tissues. Protoplasma 223, 63-66.

Martínez-Ballesta, M.C., Alcaraz-López, C., Muries, B., Mota-Cadenas, C. and Carvajal, M. (2010) Physiological aspects of rootstock-scion interactions. Scientia Horticulturae 127, 112-118.

Maxwell, K. and Johnson, G.N. (2000) Chlorophyll fluorescence - a practical guide. Journal of Experimental Botany 51, 659-668.

Mikulic-Petkovsek, M., Slatnar, A., Stampar, F. and Veberic, R. (2010) The influence of organic/ integrated production on the content of phenolic compounds in apple leaves and fruits in four different varieties over a 2-year period. Journal of the Science of Food and Agriculture 90, 2366-2378.

Milien, M., Renault-Spilmont, A.S., Cookson, S.J., Sarrazin, A. and Verdeil, J.L. (2012) Visualization of the $3 \mathrm{D}$ structure of the graft union of grapevine using X-ray tomography. Scientia Horticulturae 144, 130-140.

Miller, H. and Barnett, J.R. (1993) The structure and composition of bead-like projections on Sitka spruce callus cells formed during grafting and in culture. Annals of Botany 72, 441-448.

Mng'omba, S.A., du Toit, E.S. and Akinnifesi, F.K. (2008) The relationship between graft incompatibility and phenols in Uapaca kirkiana Muell Arg. Scientia Horticulturae 117, 212-218.

Moing, A., Salesses, G. and Saglio, P.H. (1987) Growth and the composition and transport of carbohydrate in compatible and incompatible peach plum grafts. Tree Physiology 3, 345-353.

Moore, R. (1983) Physiological aspects of graft formation. In: Moore, R. (ed.) Vegetative Compatibility Responses in Plants. Baylor Universtity Press, Waco, Texas, pp. 89-105.

Moore, R. (1991) Graft compatibilities in vitro. In: Bajaj, Y.P.S. (ed.) Biotechnology in Agriculture and Forestry, Vol. 17: High-Tech and Micropropagation I. Springer, Berlin, pp. 71-84.

Moore, R. and Walker, D.B. (1981) Study of vegetative compatibility-incompatibility in higher plants. I. A structural study of a compatible autograft in Sedum telephoides (Crassulaceae). American Journal of Botany 68, 820-830.

Mudge, K., Janick, J., Scofield, S. and Goldschmidt, E.E. (2009) A history of grafting. Horticultural Reviews 35, 437-493.

Mulkey, T.J., Kuzmanoff, K.M. and Evans, M.L. (1982) Promotion of growth and shift in the auxin dose/response relationship in maize roots treated with the ethylene biosynthesis inhibitors aminoethoxyvinylglycine and cobalt. Plant Science Letters 25, 43-48.

Musacchi, S., Pagliuca, G., Kindt, M., Piretti, M.V. and Sansavini, S. (2000) Flavonoids as markers for pear-quince graft incompatibility. Journal of Applied Botany Angewandte Botanik 74, 206-211.

Nocito, F.F., Espen, L., Fedeli, C., Lancilli, C., Musacchi, S., Serra, S., Sansavini, S., Cocucci, M. and Sacchi, G.A. (2010) Oxidative stress and senescence-like status of pear calli co-cultured on suspensions of incompatible quince microcalli. Tree Physiology 30, 450-458.

Penella, C., Nebauer, S. G., Lopéz-Galarza, S., SanBautista, A., Gorbe, E. and Calatayud, A. (2013). Evaluation for salt stress tolerance of pepper genotypes to be used as rootstocks. Journal of Food, Agriculture and Environment 11, 1101-1107.

Penella, C., Nebauer, S.G., Quiñones, A., San Bautista, A., López-Galarza, S. and Calatayud, A. (2015) Some rootstocks improve pepper tolerance to mild salinity through ionic regulation. Plant Science 230, 15-22.

Pina, A. and Errea, P. (2005) A review of new advances in mechanism of graft compatibilityincompatibility. Scientia Horticulturae 106, 1-11. 
Pina, A. and Errea, P. (2008a) Differential induction of phenylalanine ammonia-lyase gene expression in response to in vitro callus unions of Prunus spp. Journal of Plant Physiology $165,705-714$.

Pina, A. and Errea, P. (2008b) Influence of graft incompatibility on gene expression and enzymatic activity of UDP-glucose pyrophosphorylase. Plant Science 174, 502-509.

Pina, A., Errea, P., Schulz, A. and Martens, H.J. (2009) Cell-to-cell transport through plasmodesmata in tree callus cultures. Tree Physiology 29, 809-818.

Pina, A., Errea, P. and Martens, H.J. (2012) Graft union formation and cell-to-cell communication via plasmodesmata in compatible and incompatible stem unions of Prunus spp. Scientia Horticulturae 143, 144-150.

Pizzi, A. and Cameron, F.A. (1986) Flavonoid tannins - structural wood components for drought-resistance mechanisms of plants. Wood Science and Technology 20, 119-124.

Rahman, A., Amakawa, T., Goto, N. and Tsurumi, S. (2001) Auxin is a positive regulator of ethylenemediated response in the growth of Arabidopsis roots. Plant and Cell Physiology 42, 301-307.

Richardson, F.V.M., tSaoir, S.M. and Harvey, B.M.R. (1996) A study of the graft union in in vitro micrografted apple. Plant Growth Regulation 20, 7-23.

Rodrigues, C.A., Bender-Machado, L., Campos Diniz, A., Fachinello, J.C. and De Luces-Fortes, G.R. (2002) Peroxidases e fenóis totais em tecidos de porta-exertos de Prunus sp. nos períodos de crecimiento vegetativo e de donnéncia. Ciencia Rural 4, 559-564.

Santamour, F.S. (1992) Predicting graft incompatibility in woody plants. Combined Proceedings of the International Plant Propagators Society 42, 131-134.

Schöning, U. and Kollmann, R. (1997) Phoem translocation in regenerating in vitro heterografts of different compatibility. Journal of Experimental Botany 48, 289-295.

Shimomura, T. and Fujihara, K. (1977) Physiological study of graft union formation in cactus. II. Role of auxin on vascular connection between stock and scion. Journal of the Japanese Society for Horticultural Science 45, 397-406.

Singh, S., Cornilescu, C.C., Tyler, R.C., Cornilescu, G., Tonelli, M., Lee, M.S. and Markley, J.L. (2005) Solution structure of a late embryogenesis abundant protein (LEA14) from Arabidopsis thaliana, a cellular stress related protein. Protein Science 14, 2601-2609.

Slesak, I., Slesak, H., Libik, M. and Miszalski, Z. (2008) Antioxidant response system in the short-term post-wounding effect in Mesembryanthemum crystallinum leaves. Journal of Plant Physiology 165, 127-137.

Soumelidou, K., Battey, N.H., John, P. and Barnett, J.R. (1994) The anatomy of the developing bud union and its relationship to dwarfing in apple. Annals of Botany 74, 605-611.

Spiegelman, Z., Ham, B.-K., Zhang, Z., Toal, T.W., Brady, S.M., Zheng, Y., Fei, Z., Lucas, W.J. and Wolf, S. (2015) A tomato phloem-mobile protein regulates the shoot-to-root ratio by mediating the auxin response in distant organs. Plant Journal 83, 853-863.

Sterjiades, R., Dean, L.F.D., Gamble, G., Himmelsbach, D.S. and Eriksson, K.E.L. (1993) Extracellular laccases and peroxidases from sycamore maple (Acer pseudoplatanus) cell suspension cultures. Reactions with monolignols and lignin model compounds. Planta 190, 75-87.

Temperini, O., Calabrese, N., Temperini, A., Rouphael, Y., Tesid, R., Lenzi, A., Carito, A. and Colla, G. (2013) Grafting artichoke onto cardoon rootstocks: graft compatibility, yield and Verticillium wilt incidence. Scientia Horticulturae 149, 22-27.

Thomas, C.L., Bayer, E.M., Ritzenthaler, C., Fernandez-Calvino, L. and Maule, A.J. (2008) Specific targeting of a plasmodesmal protein affecting cell-to-cell communication. PLoS Biology 6, 7.

Tiedemann, R. (1989) Graft union development and symplastic phloem contact in the heterograft Cucumis sativus on Cucurbita ficifolia. Journal of Plant Physiology 134, 427-440.

Tiedemann, R. and Carsens-Behrens, U. (1994) Influence of grafting on the phloem protein patterns in Cucurbitaceae. I. Additional phloem exudate proteins in Cucumis sativus grafted on two Curcubita species. Journal of Plant Physiology 143, 189-194. 
Treutter, D. (2006) Significance of flavonoids in plant resistance and enhancement of their biosynthesis. Plant Biology 7, 581-591.

Treutter, D. and Feucht, W. (1988) Accumulation of the flavonoid prunin in P. avium/P. cerasus grafts and its possible involvement in the process of compatibility. Acta Horticulturae 227, 74-78.

Treutter, D., Galensa, R., Feucht, W. and Schmid, P.P.S. (1985) Flavanone glucosides in callus and phloem of Prunus avium: identification and stimulation of their synthesis. Physiologia Plantarum 65, 95-101.

Treutter, D., Feucht, W. and Schmid, P.P.S. (1986) Polyphenols of the phloem in relation to incompatibility of interspecific Prunus graftings (Prunus avium L., Prunus cerasus L.). 1. Flavanones and flavanols above the graft union. Gartenbauwissenschaftg 51, 77-83.

Trinchera, A., Pandozy, G., Rinaldi, S., Crinò, P., Temperini, O. and Rea, E. (2013) Graft union formation in artichoke grafting onto wild and cultivated cardoon: an anatomical study. Journal of Plant Physiology 170, 1569-1578.

Turquois, N. and Malone, M. (1996) Non-destructive assessment of developing hydraulic connections in the graft union of tomato. Journal of Experimental Botany 47, 701-707.

Usenik, V., Krska, B., Vican, M. and Stampar, F. (2006) Early detection of graft incompatibility in apricot (Prunus armeniaca L.) using phenol analyses. Scientia Horticulturae 109, 332-338.

Vermerris, W. and Nicholson, R. (2006) Isolation and identification of phenolic compounds: a practical guide. In: Phenolic Compound Biochemistry. Springer, Dordrecht, The Netherlands, pp. 151-196.

Wang, Y. and Kollmann, R. (1996) Vascular differentiation in the graft union of in vitro grafts with different compatibility - structural and functional aspects. Journal of Plant Physiology 147, 521-533.

Wang, J., Jin, Z., Yin, H., Yan, B., Ren, Z.Z., Xu, J., Mu, C.J., Zhang, Y., Wang, M.Q. and Liu, H. (2014) Auxin redistribution and shifts in PIN gene expression during Arabidopsis grafting. Russian Journal of Plant Physiology 61, 688-696.

Webster, A.D. and Schmidt, H. (1996) Rootstocks for sweet and sour cherries. In:Webster, A.D. and Looney, N.E. (eds) Cherries: Crop Physiology, Productions and Uses. CAB International, Wallingford, UK, pp. 127-163.

Yang, S., Xiang, G., Zhang, S. and Lou, C. (1992) Electrical resistance as a measure of graft union. Journal of Plant Physiology 141, 98-104.

Yin, H., Yan, B., Sun, J., Jia, P., Zhang, Z., Yan, X., Chai, J., Ren, Z., Zheng, G. and Liu, H. (2012) Graft-union development: a delicate process that involves cell-cell communication between scion and stock for local auxin accumulation. Journal of Experimental Botany 63, 4219-4232.

Yoda, H., Hiroi, Y. and Sano, H. (2006) Polyamine oxidase is one of the key elements for oxidative burst to induce programmed cell death in tobacco cultured cells. Plant Physiology 142, 193-206.

Zarrouk, O., Gogorcena, Y. and Moreno, M.A. (2006) Graft compatibility between peach cultivars and Prunus rootstocks. HortScience 41, 1389-1394.

Zarrouk, O., Testillano, P.S., Risueño, M.C., Moreno, M.Á. and Gogorcena, Y. (2010) Changes in cell/tissue organization and peroxidase activity as markers for early detection of graft incompatibility in peach/plum combinations. Journal of the American Society for Horticultural Science 135, 9-17.

Zheng, B.S., Chu, H.L., Jin, S.H., Huang, Y.J., Wang, Z.J., Chen, M. and Huang, J.Q. (2010) CDNA-AFLP analysis of gene expression in hickory (Carya cathayensis) during graft process. Tree Physiology 30, 297-303. 